\title{
Regional R\&D Investment and New Product Development Performance of Enterprises under the Background of Knowledge Activities
}

\author{
Hui Xu \\ College of Economics, Jinan University, Guangzhou, China \\ Email: jnuxuhui@163.com
}

How to cite this paper: $\mathrm{Xu}, \mathrm{H}$. (2018) Regional R\&D Investment and New Product Development Performance of Enterprises under the Background of Knowledge Activities. Open Journal of Social Sciences, 6, 183-199.

https://doi.org/10.4236/jss.2018.63013

Received: March 5, 2018

Accepted: March 25, 2018

Published: March 28, 2018

Copyright $\odot 2018$ by author and Scientific Research Publishing Inc. This work is licensed under the Creative Commons Attribution International License (CC BY 4.0).

http://creativecommons.org/licenses/by/4.0/

\begin{abstract}
The theory of innovation factor thinks that regional research and development (R\&D) investment directly affects the new product development (NPD) performance of the enterprise, while the theory of innovation efficiency considers that regional R\&D investment affects the NPD performance of the enterprise by affecting the enterprise internal $R \& D$ efficiency. To test the two-theoretical hypothesis, we match up Chinese provincial-level data with the enterprise data from China industrial enterprise database. The empirical results show that, the theory of innovation factor and the theory of innovation efficiency exist simultaneously. The regional R\&D investment can affect NPD performance of enterprises. However, R\&D investment of other enterprises in the same region has a beneficial impact on the enterprise internal R\&D efficiency. And the regional $R \& D$ investment in human resources has a positive effect on the enterprise internal $R \& D$ efficiency. According to the conclusions, this paper constructs three policy advices, which are increasing regional $\mathrm{R} \& \mathrm{D}$ investment, expanding and consolidating the enterprise as the core of the status of $R \& D$ and increasing regional $R \& D$ investment in human resources.
\end{abstract}

\section{Keywords}

Regional R\&D Investment, R\&D Efficiency, Knowledge-Based View, Hierarchical Linear Modeling

\section{Introduction}

In a market economy, the competitive advantages of enterprises come from the new products [1]. The R\&D capability directly affects whether the enterprises 
can survive in the fierce market competition. The NPD performance of enterprises as an important embodiment of measuring the R\&D capability will inevitably draw people's attention consequently.

While enterprises urgently need to increase the performance of NPD, another phenomenon has drawn our attention, namely, the ever-increasing investment in $R \& D$. To obtain the ability of sustainable development and enhance the market competitiveness of enterprises, the government and enterprises have continuously increased their investment in R\&D activities. The R\&D expenditure of China increased from 304 billion yuan in 2007 to 15,677 billion yuan in 2016, an increase of 4 times in 10 years. Among them, government investment increased from 91 billion yuan to 314 billion yuan, an increase of 2.4 times in 10 years.

Under the background of increasing $R \& D$ investment and the urgent need for NPD, a large amount of research focuses on the "black box" relationship between R\&D investment and enterprise NPD. However, there is no literature to directly study the relationship between regional R\&D investment and NPD performance of enterprises. Among the many factors related to the NPD performance of the enterprise, whether regional R\&D investment as an external factor affects the performance of NPD of the enterprise depends on the production and operation of the enterprise. This is of great practical significance. Many studies have shown that different $R \& D$ investment in enterprises will lead to different performance of NPD [2] [3] [4]. However, for enterprises located in different regions, whether regional R\&D investment affects NPD performance of the enterprise is still unclear. And as for how regional R\&D investment influences the NPD of the enterprise, there is no empirical study on this subject currently.

\section{Theoretical Framework and Research Hypothesis}

\subsection{Theoretical Framework}

Enterprises as the main subject of NPD belong to micro-level and individual level. The region as R\&D environment belongs to macro-level and overall level. From the point of view of NPD, the enterprise as a microscopic subject is always nested in a specific regional environment, and they form a hierarchical relationship [5] [6]. However, general multiple regression model put environmental variables and enterprise variables into a model directly, which means the enterprise and environment belong to the same level. This is obviously inconsistent with the reality. Regional R\&D investment, R\&D investment of enterprises and NPD of enterprise belong to two levels respectively. Under this hierarchical relationship, regional $\mathrm{R} \& \mathrm{D}$ investment as a regional factor can directly affect the performance of NPD of enterprises and this process does not depend on other factors, which be called the direct effect. Regional R\&D investment indirectly affects the performance of NPD by influencing the relationship between enterprise R\&D investment and NPD performance, and that is changing the NPD performance of enterprise by affecting internal R\&D efficiency. Baron and Kenny de- 
fined it as a moderate effect [7]. The two effects are shown in Figure 1.

Knowledge-based view (KBV) considers that new product development is the process of knowledge activities of enterprises, which is divided into knowledge acquisition, integration and creation. In addition, knowledge creation is a dynamic process of knowledge acquisition and integration, and that is the process of expanding and internalizing internal knowledge [8]. The role of $R \& D$ investment in NPD is that promotes the internal knowledge acquisition and integration proactively and provides additional material motivation for the dynamic process of knowledge creation within enterprises. Compared to enterprises with only spontaneous knowledge activities, R\&D investment accelerates the knowledge activities within enterprises. Therefore, the R\&D investment of enterprises will have a positive impact on the performance of NPD. The direct effect and the moderate effect of regional R\&D investment are the effects of external knowledge activities on the internal knowledge activities. Among them, the regional $\mathrm{R} \& \mathrm{D}$ investment can have an impact on the internal $\mathrm{R} \& \mathrm{D}$ efficiency, which is called the theory of innovation efficiency [9]. R\&D-driven knowledge activities directly provide enterprises with innovative knowledge and talent, and these factors directly affect solving the problems in the development of new products. There is a direct effect on the performance of NPD, and this mechanism is called the theory of innovation factor [10].

This article takes KBV as the theoretical background of the whole framework. The knowledge activities of external R\&D institutions, other enterprises and colleges are collectively called the external knowledge activities. Through the external knowledge activities influencing the internal knowledge activities, we connect enterprise and environment and build a theory model that regional $\mathrm{R} \& \mathrm{D}$ investment influence the NPD performance of enterprises, which shown in Figure 2 .

\subsection{Research Hypothesis}

KBV considers that the enterprise knowledge has two dimensions: depth and breadth [11] [12] [13]. And the depth of knowledge refers to the degree of enterprise reuse knowledge in a field, which reflects the enterprise knowledge in a field. Breadth is how often enterprise use the latest knowledge, which reflects the range of up-to-date knowledge that enterprise can access. Enterprise knowledge

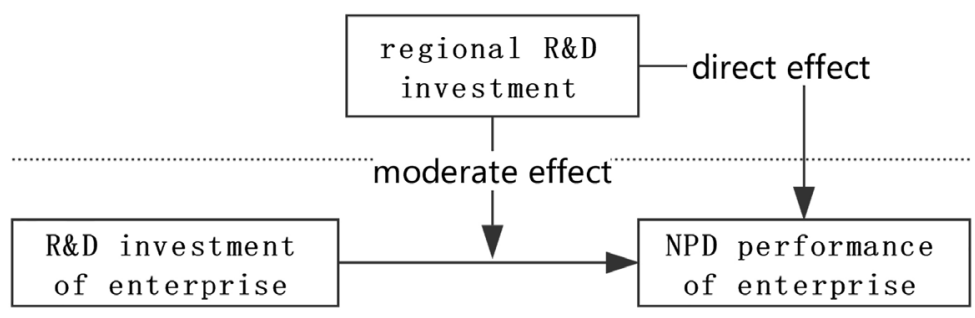

Figure 1. Direct effect and moderate effect. 


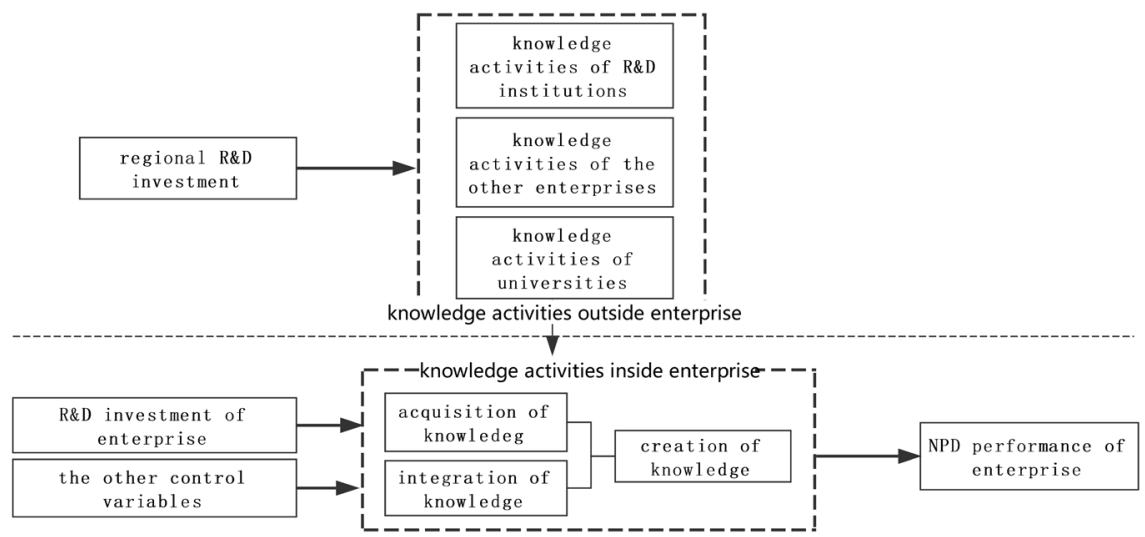

Figure 2. Theoretic framework of this article.

acquisition is an extension of these two dimensions. Knowledge can be reused to deepen the understanding of knowledge in a certain area. Individuals may gain more important and complicated knowledge through the epiphany to solve the problems appearing in the process of NPD creatively [14]. The more knowledge enterprise reserves, the more likely to develop new regulations, processes and problem-solving methods [15]. The extension of enterprise knowledge depth and breadth will have a significant positive impact on enterprise innovation and NPD capacity [16] [17].

Enterprise knowledge is divided into explicit knowledge and tacit knowledge according to the degree of knowledge transfer and the way of delivery [18]. Explicit knowledge can be expressed through various media including languages, scripts, symbols, formulas, codes, etc., which are generally considered as public goods by economists. The cost of transfer is very low, and the marginal cost of adding additional users is close to zero. However, tacit knowledge can only be expressed by application. And the characteristic of it is the speed of transmission in the population will be slow, the cost is high, and the result of transfer is full of uncertainty [19] [20]. The main subject carrying knowledge is divided into four levels: Individual, Group, Organization, Interorganizational domain. Combined with Nonaka's SECI theory, the integration of enterprise knowledge has two dimensions. First, from the perspective of epistemology, the transformation between tacit knowledge and explicit knowledge is the dimension of "tacit knowledge - explicit knowledge." Second, from the perspective of ontology, transformation between different subject carrying knowledge is the dimension of "individual knowledge - common knowledge" [21]. Enterprise knowledge is continuously transformed in these two dimensions along with the expansion of enterprise knowledge in depth and breadth, which forms a spiral transformation alternately. Knowledge creation is also continuously circulated in spiral transformation, and the level of enterprise innovation has been enhanced in each cycle [22]. The enterprise knowledge base of innovation will also be expanded in each cycle. All these will contribute to help enterprises solve problems in NPD.

Therefore, the efficiency of internal R\&D can be understood as the efficiency of R\&D investment to promote the spiral transformation of knowledge. Know- 
ledge space agglomeration theory holds that powerful knowledge activities outside the enterprise will form a knowledge gathering space. In this space, knowledge exchange and collision often occur. It forms a gathering space for knowledge transformation, integration and creation, which changes knowledge spiral transformation by alter unidimensional, closed and linear. All these will help to improve the efficiency of spiral transformation of knowledge. Therefore, from the appearance point of view, enterprises in the same region can make use of the advantages in space, which makes enterprise easier to obtain new knowledge through cooperation. This will help enterprises to deepen the knowledge depth and broaden the knowledge breadth so that enterprises can provide solutions to handle the problem in NPD and improve NPD performance. In addition to the new knowledge, the fruit of the R\&D investment in the region also has innovative knowledge talents. The greater the R\&D investment in a region, the greater intensity of corresponding knowledge activities and the more trained personnel, which helps enterprises to recruit the right people, get more tacit knowledge, cultivate innovative talents, and improve the performance of NPD.

Therefore, this paper proposes the following assumption:

H1: Regional R\&D investment has both direct and moderate effects on the NPD performance of enterprises, which means the theory of innovation factor and the theory of innovation efficiency are both established.

\section{Sample Selection and Variable Description}

\subsection{Sample Selection}

At the macro level, this paper uses the internal expenditures data of regional research funds in the 2007 China Science and Technology Statistics Year book and selects 31 provinces except Taiwan, Hong Kong and Macau with provinces as the standard of regional division. At the micro level, this paper chooses the enterprise samples that meet the requirements in the 2007 China Industrial Enterprise Database. Since the latest official statistics in 2007, we can only select data in 2007. But due to the large amount of data, the nature of the data will not change much. Therefore, we do not think old data will affect the empirical results of this article seriously.

First, we exclude the enterprise samples of which total industrial output value, fixed assets, total assets, salary, business status and enterprise code are missing or abnormal or duplicate with reference to Cai and Qianli Xie [23] [24]. And then we exclude the enterprise samples of which total assets less than current assets, total assets less than fixed assets, accumulated depreciation less than current depreciation, etc., which do not meet the accounting system. Eventually we obtained about 320,000 enterprise samples.

\subsection{Variable Description}

The variables of this model are divided into dependent variable, independent variable and control variable, as shown in Table 1. 
Table 1. Explanation for each variable.

\begin{tabular}{|c|c|c|c|}
\hline Types of variables & Index & Symbol & Describe \\
\hline Dependent variable & NPD performance & NPD & $\begin{array}{c}\text { Output of new product/gross } \\
\text { output }\end{array}$ \\
\hline \multirow{9}{*}{$\begin{array}{c}\text { Microscopic } \\
\text { independent } \\
\text { variables }\end{array}$} & $\begin{array}{l}\mathrm{R} \& \mathrm{D} \text { investment of } \\
\text { enterprise }\end{array}$ & $\mathrm{RD}$ & $\begin{array}{c}\text { R\&D expenditure of } \\
\text { enterprise/major business income }\end{array}$ \\
\hline & regional $\mathrm{R} \& \mathrm{D}$ investment & area_rd & Regional R\&D expenditure/GDP \\
\hline & $\begin{array}{l}\mathrm{R} \& \mathrm{D} \text { investment in } \mathrm{R} \& \mathrm{D} \\
\text { institutions }\end{array}$ & lab_rd & $\begin{array}{l}\text { All institutions R\&D } \\
\text { expenditure/GDP }\end{array}$ \\
\hline & $\begin{array}{l}\mathrm{R} \& \mathrm{D} \text { investment in all } \\
\text { enterprises }\end{array}$ & firm_rd & $\begin{array}{l}\text { All enterprises R\&D } \\
\text { expenditure/GDP }\end{array}$ \\
\hline & $\begin{array}{l}\mathrm{R} \& \mathrm{D} \text { investment in } \\
\text { universities }\end{array}$ & college_rd & $\begin{array}{l}\text { All universities R\&D } \\
\text { expenditure/GDP }\end{array}$ \\
\hline & $\begin{array}{l}\mathrm{R} \& \mathrm{D} \text { investment in human } \\
\text { resource }\end{array}$ & wage_rd & $\begin{array}{l}\mathrm{R} \& \mathrm{D} \text { expenditure in human } \\
\text { resources/GDP }\end{array}$ \\
\hline & $\begin{array}{l}\mathrm{R} \& \mathrm{D} \text { investment in material } \\
\text { resource }\end{array}$ & inf_rd & $\begin{array}{l}\mathrm{R} \& D \text { expenditure in material } \\
\text { resources/GDP }\end{array}$ \\
\hline & $\begin{array}{l}\text { salary and welfare income per } \\
\text { capita }\end{array}$ & wage & $\begin{array}{l}\text { The logarithmic form of per } \\
\text { capita wage and welfare }\end{array}$ \\
\hline & education costs per capita & edu & $\begin{array}{l}\text { The logarithm of the education } \\
\text { cost per person }\end{array}$ \\
\hline \multirow[t]{3}{*}{ Control variables } & government subsidy & subsidy & 0 is no subsidy, 1 is subsidized \\
\hline & enterprise scale & size & $\begin{array}{c}\text { The logarithmic form of total } \\
\text { assets }\end{array}$ \\
\hline & enterprise ownership & ownership & $\begin{array}{c}0 \text { is the private enterprise, } 1 \text { is the } \\
\text { public-owned enterprise }\end{array}$ \\
\hline
\end{tabular}

- Dependent Variable: The dependent variable in this paper is the performance of NPD, which expressed as the ratio of the output value of new products to the total industrial output value. The ratio is used to make the index value of different enterprises comparable and to exclude other factors such as enterprise size.

- Independent Variables: According to multiple linear model set, the independent variables can be divided into microscopic independent variables and macroscopic independent variables. And the microscopic independent variables are enterprise spending on $R \& D$, which expressed as the ratio of $R \& D$ costs to primary business income. Macroscopic independent variable is the regional $R \& D$ investment, which is expressed as the ratio of the expenditure of regional R\&D to the regional GDP. According to the knowledge activity of different subjects, we divided regional $R \& D$ investment in to enterprise, $R \& D$ institutions and university, which expressed as the ratio of their corresponding R\&D expenditure to the regional GDP. According to the different usage, we divided regional $\mathrm{R} \& \mathrm{D}$ investment into human resources investment and material resources investment, which expressed as the ratio of the incorresponding R\&D expenditure to the regional GDP.

- Control Variables: The control variables focus on the enterprise level. The contribution of enterprises to human resources of workers will also exert an influence on the innovation of enterprises. There are two parts in human resources investment: wages and educational expenditure. They are expressed 
as the logarithm of the average salary per worker and the average educational expenditure per worker. The government tends to subsidize innovative industries or innovative enterprises. This article uses government subsidies to control this factor. In addition, enterprises of varied sizes and ownership systems will have different capability of NDP. This article uses the total amount of assets and enterprise ownership to control the impact of these factors on the results.

\section{Empirical Test}

The traditional linear regression model can only analyze data that involves only one layer and cannot reflect the relationship between variables in different layers [25]. Therefore, this article does not use the traditional linear regression model to research the moderate effect of regional R\&D investment. While hierarchical linear modeling is appropriate for nested structure data [26]. And the basic assumption of linearity and normality of the linear model is retained. The traditional error term is divided into two parts, that is, the error between the enterprise level and the regional level is independent. So that each region can have a different regression model that reflects the relationship between the region and the enterprise level. Therefore, it is suitable for studying the impact of regional $\mathrm{R} \& \mathrm{D}$ investment on the NPD performance of enterprises.

\subsection{Model Settings}

\section{1) Zero Model}

The first and second layer of model does not contain independent variables, only the intercept, that is, for analysis of variance component. It can be used to illustrate the differences between regions can explain the degree of variance of NPD performance of enterprises. Whether there is a significant difference in the NPD performance of enterprise in different regions decides the rationality of using a hierarchical linear modeling.

Level 1: $\mathrm{NPD}_{i j}=\beta_{0 j}+\varepsilon_{i j}$

Level 2: $\beta_{0 j}=\gamma_{00}+\mu_{0 j}$

Mixed: $\mathrm{NPD}_{i j}=\gamma_{00}+\mu_{0 j}+\varepsilon_{i j}$

2) Covariance Model

Covariance model only have the first layer that contains the independent variables, and the second layer does not contain independent variables. In this paper, we join the enterprise R\&D investment and other control variables in the first layer of the model. At this point, the first layer of the intercept and enterprise R\&D investment slope of the regression coefficient is set to the second layer of the dependent variable. The intercept term is the random effect, and the slope term is the fixed effect.

Level 1: $\quad \mathrm{NPD}_{i j}=\beta_{0 j}+\beta_{1 j} * \mathrm{RD}+\beta_{p j} *$ control variables $+\varepsilon_{i j}$

Level 2: $\beta_{0 j}=\gamma_{00}+\mu_{0 j} \quad \beta_{1 j}=\gamma_{10}$

Mixed: $\mathrm{NPD}_{i j}=\gamma_{00}+\mu_{0 j}+\gamma_{10} * \mathrm{RD}+\beta_{p j} *$ control variables $+\varepsilon_{i j}$ 


\section{3) Random Coefficient Model}

The basic set-up is the same as the covariance model except that the slope of the $\mathrm{R} \& \mathrm{D}$ investment in the second layer is replaced by the random effect. By comparing with the result of the covariance model, we can determine whether there is a random effect in the dependent variable of the second level of the model.

Level 1: $\quad \mathrm{NPD}_{i j}=\beta_{0 j}+\beta_{1 j} * \mathrm{RD}+\beta_{p j} *$ control variables $+\varepsilon_{i j}$

Level 2: $\beta_{0 j}=\gamma_{00}+\mu_{0 j}$

$$
\beta_{1 j}=\gamma_{10}+\mu_{1 j}
$$

Mixed: $\mathrm{NPD}_{i j}=\gamma_{00}+\mu_{0 j}+\gamma_{10} * \mathrm{RD}+\mu_{1 j} * \mathrm{RD}+\beta_{p j} *$ control variables $+\varepsilon_{i j}$

4) Situational Model

The first layer is a complete model including enterprise R\&D investment and all control variables. The first layer intercept term is the second layer dependent variable, and then selecting the macro-independent variables as the first layer intercept item's independent variables. According to whether there is a random effect of slope of the model in the second layer, the situational model is divided into a fixed situational model and a random situational model.

Level 1: $\mathrm{NPD}_{i j}=\beta_{0 j}+\beta_{1 j} * \mathrm{RD}+\beta_{p j} *$ control variables $+\varepsilon_{i j}$

Level 2: $\beta_{0 j}=\gamma_{00}+\gamma_{0 k} *$ macro-independent variables $+\mu_{0 j}$ $\beta_{1 j}=\gamma_{10}$ (fixed situational model) or $\beta_{1 j}=\gamma_{10}+\mu_{1 j}$ (random situational model)

$$
\begin{aligned}
& \text { Mixed: } \begin{array}{r}
\mathrm{NPD}_{i j}=\gamma_{00}+\mu_{0 j}+\gamma_{0 k} * \text { macro-independent variables }+\gamma_{10} * \mathrm{RD} \\
\\
+\beta_{p j} * \text { control variables }+\varepsilon_{i j}(\text { fixed situational model })
\end{array} \\
& \mathrm{NPD}_{i j}= \gamma_{00}+\mu_{0 j}+\gamma_{0 k} * \text { macro-independent variables }+\gamma_{10} * \mathrm{RD} \\
&+\mu_{1 j} * \mathrm{RD}+\beta_{p j} * \text { control variables }+\varepsilon_{i j}(\text { random situational model })
\end{aligned}
$$

\section{5) Complete Model}

The first layer includes R\&D investment and control variables. Then the first layer of intercept and the $\mathrm{R} \& \mathrm{D}$ input slope of the enterprise are the dependent variable of the second layer. The second layer contains the macro-independent variables and error terms. So, there is a random effect in this model.

Level 1: $\mathrm{NPD}_{i j}=\beta_{0 j}+\beta_{1 j} * \mathrm{RD}+\beta_{p j} *$ control variables $+\varepsilon_{i j}$

Level 2: $\beta_{0 j}=\gamma_{00}+\gamma_{0 k} *$ macro-independent variables $+\mu_{0 j}$

$$
\beta_{1 j}=\gamma_{10}+\gamma_{1 k} * \text { macro-independent variables }+\mu_{1 j}
$$$$
\mathrm{NPD}_{i j}=\gamma_{00}+\mu_{0 j}+\gamma_{0 k} * \text { macro-independent variables }+\gamma_{10} * \mathrm{RD}
$$

Mixed: $\quad+\mu_{1 j} * \mathrm{RD}+\gamma_{1 k} *$ macro-independent variables $* \mathrm{RD}$

$$
+\beta_{p j} * \text { control variables }+\varepsilon_{i j}
$$

\subsection{Model Results Analysis}

Prior to the model calculation, we centralize the selected index data to avoid the problem of multiple collinearity caused by interaction items. And then we calculate the correlation coefficient between each independent variable in the complete model, which shown in Table 2. 
Table 2. Correlation coefficient of each variable.

\begin{tabular}{ccccccccc}
\hline & $\mathrm{RD}$ & subsidy & ownership & size & wage & edu & area_rd & RD*area_rd \\
\hline RD & 1.0000 & & & & & & & \\
subsidy & 0.0839 & 1.0000 & & & & & & \\
ownership & 0.0373 & 0.0696 & 1.0000 & & & & & \\
size & 0.0902 & 0.2360 & 0.2438 & 1.0000 & & & & \\
wage & 0.1004 & 0.0612 & 0.1163 & 0.3294 & 1.0000 & & & \\
edu & 0.0579 & 0.0015 & 0.0789 & 0.0249 & 0.1964 & 1.0000 & & \\
area_rd & 0.1155 & 0.0389 & 0.0214 & 0.0228 & 0.2149 & 0.0248 & 1.0000 & \\
RD*area_rd & 0.4460 & 0.0077 & 0.0302 & 0.0177 & 0.0645 & 0.0247 & 0.2252 & 1.0000 \\
\hline
\end{tabular}

As can be seen from Table 2, there is no high correlation between the relevant variables. And by variance inflation factor test, Table 3 shows that the maximum VIF value is 1.30 and the minimum is 1.05 , so there is no serious multicollinearity problem in this model.

We take the corresponding index data into the zero model and calculate the zero model results. The results are shown in Table 4.

As can be seen from Table 3, the average NPD performance of enterprises is 0.0339. The variance of NPD performance in the different provinces in second layer is 0.0015 , while the variance of NPD performance of different enterprise in the first layer is 0.024 . Thus, the correlation coefficient ICC value is 0.0588 , which indicates that the difference of about $5.9 \%$ in the NPD performance of enterprises can be explained by the difference of provinces. And the likelihood ratio test value is 14114.50 , which is much higher than that of 1 degree of freedom with a $1 \%$ significance level. So, test result rejects the null hypothesis that the performance of NPD among regions is equal. And there is a significant difference in the NPD performance among different regions. Therefore, it is appropriate that this paper uses a hierarchical linear modeling to study the impact of regional $\mathrm{R} \& \mathrm{D}$ investment on the performance of NPD.

The results of the covariance model, the random coefficient model, the situational model and the complete model are shown in Table 5.

It can be seen from Table 5 that the R\&D investment coefficient of enterprises is both positive and significant at the level of $1 \%$. Consistent with most of the findings, the R\&D investment of enterprises has a significant positive impact on NPD performance. From view of the control variables, all the control variables have a significant impact on the performance of new product development. In the aspect of enterprise human resources input, the more enterprises invest in staff education, the higher the performance of NPD enterprises have. The higher per employee salary enterprises give, the higher the performance of NPD enterprises have. In terms of enterprise ownership, the coefficient is significantly less than 0 , which indicates that the NPD performance of public-owned enterprises 
Table 3. VIF of each variable.

\begin{tabular}{ccc}
\hline Variables & VIF & $1 /$ VIF \\
\hline RD*area_rd & 1.30 & 0.7886 \\
RD & 1.27 & 0.7867 \\
size & 1.25 & 0.7995 \\
wage & 1.23 & 0.8123 \\
area_rd & 1.11 & 0.9045 \\
ownership & 1.07 & 0.9340 \\
subsidy & 1.07 & 0.9375 \\
edu & 1.05 & 0.9529 \\
Mean VIF & 1.17 & \\
\hline
\end{tabular}

Table 4. Results of zero model.

\begin{tabular}{ccccc}
\hline Dependent variable Intercept term & Variance among regional & Variance among enterprises & \multicolumn{2}{c}{ LR } \\
\hline NPD & $\begin{array}{c}0.0339^{* * *} \\
(4.89)\end{array}$ & 0.0015 & 0.0240 & $\begin{array}{c}14114.50 \\
* * *\end{array}$
\end{tabular}

a. ${ }^{*}{ }^{* *},{ }^{* *}$, at $10 \%, 5 \%, 1 \%$ significant level.

Table 5. Results of different models.

\begin{tabular}{|c|c|c|c|c|}
\hline $\begin{array}{l}\text { Independent } \\
\text { variables }\end{array}$ & Covariance Model & Random Coefficient Model & Situational Model & Complete Model \\
\hline \multirow{2}{*}{$\mathrm{RD}$} & $1.6210^{* * *}$ & $1.4740^{\star * *}$ & $1.4942^{\star * *}$ & $1.5309^{\star * *}$ \\
\hline & $(63.78)$ & $(7.23)$ & $(7.30)$ & $(7.67)$ \\
\hline \multirow{2}{*}{ subsidy } & $0.0190^{* * *}$ & $0.1719^{* * *}$ & $0.0172^{* * *}$ & $0.0172^{* * *}$ \\
\hline & $(14.62)$ & $(13.28)$ & (13.29) & $(13.29)$ \\
\hline \multirow[b]{2}{*}{ ownership } & $-0.0042^{\star * \star}$ & $-0.0036^{\star * *}$ & $-0.0036^{\star * \star}$ & $-0.0036^{\star * \star}$ \\
\hline & $(-3.14)$ & $(-2.73)$ & $(-2.74)$ & $(-2.74)$ \\
\hline \multirow{2}{*}{ size } & $0.0158^{* * *}$ & $0.0157^{\star * *}$ & $0.0157^{\star * *}$ & $0.0157^{\star * *}$ \\
\hline & $(44.84)$ & $(44.69)$ & $(44.68)$ & $(44.69)$ \\
\hline \multirow{2}{*}{ wage } & $0.0062^{* * *}$ & $0.0057^{\star * *}$ & $0.0056^{* * *}$ & $0.0056^{* * *}$ \\
\hline & $(6.14)$ & $(5.67)$ & $(5.59)$ & $(5.59)$ \\
\hline \multirow{2}{*}{ edu } & $0.0018^{* * *}$ & $0.0016^{\star * *}$ & $0.0016^{\star * *}$ & $0.0016^{* * *}$ \\
\hline & $(5.01)$ & $(4.47)$ & $(4.48)$ & $(4.48)$ \\
\hline area_rd & & & $\begin{array}{c}2.9725^{\star * *} \\
(6.43)\end{array}$ & $\begin{array}{c}3.1657^{\star * *} \\
(6.56)\end{array}$ \\
\hline $\mathrm{RD}^{*}$ area_rd & & & & $\begin{array}{c}28.5358 \\
(1.44)\end{array}$ \\
\hline Interceptterm & $\begin{array}{c}-0.1406^{\star * *} \\
(-16.34)\end{array}$ & $\begin{array}{c}-0.1378^{\star * *} \\
(-16.77)\end{array}$ & $\begin{array}{c}-0.1318^{\star \star *} \\
(-21.37)\end{array}$ & $\begin{array}{c}-0.1314^{* * *} \\
(-21.33)\end{array}$ \\
\hline Log likelihood & 44192.598 & 45187.478 & 45200.177 & 45201.175 \\
\hline
\end{tabular}

a. ${ }^{*}{ }^{* *},{ }^{* *}$, at $10 \%, 5 \%, 1 \%$ significant level.

is less than that of private-owned enterprises. Private-owned enterprises have stronger innovation ability than public-owned enterprises. Enterprises in innovative industries are generally more likely to get government subsidies. Therefore, government-subsidized enterprises have significantly higher performance in developing new products than other enterprises. 
Regional R\&D investment coefficient was significantly positive, and it indicates that $R \& D$ investment in the region has a positive direct effect on the performance of NPD, which meets the hypothesis of innovative factors. However, the interaction coefficient between regional $R \& D$ investment and enterprise R\&D investment is not significant, and the complete model cannot pass the likelihood ratio test, which shows that regional $R \& D$ investment cannot explain the difference in coefficient of enterprise $R \& D$ investment. The moderate effect of the relationship between enterprise R\&D investment and NPD performance is not significant. Therefore, the hypothesis of innovation efficiency is not valid here.

According to the main subject of knowledge activity, the R\&D investment in the region is divided into three parts. The following are the research results of effect $R \& D$ investment in $R \& D$ institutions, $R \& D$ investment in the other enterprises and $R \& D$ investment in universities have on the NPD performance of enterprise. The complete model contains the most information to facilitate the judgment of the relationship between the variables, so this paper chose to use the complete model to study the above problems. The calculation results are shown in Table 6.

As can be seen from Table 6, the interaction coefficient between R\&D input of other enterprises in the region and R\&D input of the enterprise is 120.1524,

Table 6. Complete model results of different regional R\&D investment.

\begin{tabular}{|c|c|c|c|}
\hline Independent variables & $\mathrm{R} \& \mathrm{D}$ institutions & All enterprises & Universities \\
\hline $\mathrm{RD}$ & $\begin{array}{c}1.4588^{* * *} \\
(7.07)\end{array}$ & $\begin{array}{c}1.7540^{* * *} \\
(7.62)\end{array}$ & $\begin{array}{c}1.4610^{* * *} \\
(7.25)\end{array}$ \\
\hline subsidy & $\begin{array}{c}0.0172^{* * *} \\
(13.28)\end{array}$ & $\begin{array}{c}0.0172^{* * *} \\
(13.29)\end{array}$ & $\begin{array}{c}0.0172^{* * *} \\
(13.30)\end{array}$ \\
\hline ownership & $\begin{array}{c}-0.0036^{* * *} \\
(-2.77)\end{array}$ & $\begin{array}{c}-0.0036^{\star * *} \\
(-2.71)\end{array}$ & $\begin{array}{c}-0.0037^{\star * *} \\
(-2.79)\end{array}$ \\
\hline size & $\begin{array}{c}0.0157^{\star * *} \\
(44.67)\end{array}$ & $\begin{array}{c}0.0157^{\star * *} \\
(44.69)\end{array}$ & $\begin{array}{c}0.0157^{\star * *} \\
(44.68)\end{array}$ \\
\hline wage & $\begin{array}{c}0.0057^{* * *} \\
(5.65)\end{array}$ & $\begin{array}{c}0.0057^{* * *} \\
(5.65)\end{array}$ & $\begin{array}{c}0.0056^{* * *} \\
(5.62)\end{array}$ \\
\hline edu & $\begin{array}{c}0.0016^{* * *} \\
(4.47)\end{array}$ & $\begin{array}{c}0.0016^{* * *} \\
(4.48)\end{array}$ & $\begin{array}{c}0.0016^{* * *} \\
(4.48)\end{array}$ \\
\hline labor_rd & $\begin{array}{c}5.1454^{* * *} \\
(4.28)\end{array}$ & & \\
\hline RD*labor_rd & $\begin{array}{c}18.6967 \\
(0.45)\end{array}$ & & \\
\hline firm_rd & & $\begin{array}{c}4.6658^{* *} \\
(2.32)\end{array}$ & \\
\hline $\mathrm{RD}{ }^{\star}$ firm_rd & & $\begin{array}{c}120.1524^{* *} \\
(2.08)\end{array}$ & \\
\hline college_rd & & & $\begin{array}{c}31.7014^{* * *} \\
(7.67)\end{array}$ \\
\hline $\mathrm{RD}^{*}$ college_rd & & & $\begin{array}{c}214.8706 \\
(1.13)\end{array}$ \\
\hline Intercept term & $\begin{array}{c}-0.1411^{* * *} \\
(-20.22)\end{array}$ & $\begin{array}{c}-0.1262^{\star * *} \\
(-13.72)\end{array}$ & $\begin{array}{c}-0.1399^{* * *} \\
(-24.20)\end{array}$ \\
\hline
\end{tabular}

a. ${ }^{*}, * * * *$, at $10 \%, 5 \%, 1 \%$ significant level. 
that is significantly positive at $5 \%$ level. This shows that R\&D investment of other enterprises in the region positively moderate relationship between $R \& D$ investment and NPD performance in the enterprise. R\&D investment of other enterprises in the region has a significant positive impact on R\&D efficiency within the enterprise, which proves the same holds true for the hypothesis of innovation efficiency. However, the moderate effects of R\&D investment of R\&D institutions and universities are not significant, although the mutual coefficients of $R \& D$ investment of $R \& D$ institutions, $R \& D$ investment of universities and $R \& D$ investment of enterprise are positive, and the coefficients are not significant. Therefore, the impact of $R \& D$ investment of $R \& D$ institutions and universities on $\mathrm{R} \& \mathrm{D}$ efficiency of enterprises is also not significant. The results show that the interaction among knowledge-based activities among regional enterprises is more prominent and relevant, while the knowledge activities correlation between R\&D institutions, universities and enterprise is relatively weak.

\subsection{Robustness Test}

To verify the robustness and reliability of the model results, this paper also extracted the data of science and technology expenditure in "China Science and Technology Statistics Yearbook". Since science and technology expenditure and R\&D investment are all essentially promotion of knowledge activities and creation. These data can also well reflect the situation of knowledge activities in the region. And the theoretical framework of this article is still in place. The original regional $\mathrm{R} \& \mathrm{D}$ expenditure is replaced by science and technology expenditure. Using a complete hierarchical linear model, we explore the impact of different science and technology expenditure in the region on the internal NPD performance. The results are shown in Table 7 . The results show that only the investment in science and technology from other enterprises in the region has a significant impact on the internal R\&D efficiency. The results are basically the same as those in Table 6, and the results are stable.

\subsection{Further Research}

As the Statistical Yearbook further divides the regional science and technology input into labor costs to measure human resources investment and fixed assets construction cost to measure the investment in material resources, this paper can also continue to study the impact of $R \& D$ investment in two different resources on the NPD performance of enterprise. Continue to use the above models and methods, and the complete model results shown in Table 8.

Table 8 shows that the interaction coefficient between regional R\&D investment in human resources and enterprise $R \& D$ investment is 86.2877 , that is significant at $10 \%$ level. This indicates that regional $\mathrm{R} \& \mathrm{D}$ investment in human resources has a significant positive moderate effect on the performance of NPD. The regional R\&D investment in human resources has a significant positive impact on the enterprise internal $R \& D$ efficiency, while the impact of regional $R \& D$ 
Table 7. Results of robustness test.

\begin{tabular}{|c|c|c|c|}
\hline Independent variables & R\&D institutions & All enterprises & Universities \\
\hline $\mathrm{RD}$ & $\begin{array}{c}1.4566^{\star * *} \\
(7.05)\end{array}$ & $\begin{array}{c}1.6524^{\star * *} \\
(7.70)\end{array}$ & $\begin{array}{c}1.4603^{* * *} \\
(7.20)\end{array}$ \\
\hline subsidy & $\begin{array}{c}0.0172^{\star * \star} \\
(13.28)\end{array}$ & $\begin{array}{c}0.0172^{\star * *} \\
(13.28)\end{array}$ & $\begin{array}{c}0.0172^{\star * *} \\
(13.29)\end{array}$ \\
\hline ownership & $\begin{array}{c}-0.0036^{* * *} \\
(-2.78)\end{array}$ & $\begin{array}{c}-0.0036^{* * *} \\
(-2.72)\end{array}$ & $\begin{array}{c}-0.0036^{* * *} \\
(-2.79)\end{array}$ \\
\hline size & $\begin{array}{c}0.0157^{\star * \star} \\
(44.67)\end{array}$ & $\begin{array}{c}0.0157^{\star * *} \\
(44.69)\end{array}$ & $\begin{array}{c}0.0157^{\star * *} \\
(44.69)\end{array}$ \\
\hline wage & $\begin{array}{c}0.0057^{\star * *} \\
(5.65)\end{array}$ & $\begin{array}{c}0.0057^{* * *} \\
(5.66)\end{array}$ & $\begin{array}{c}0.0056^{* * *} \\
(5.63)\end{array}$ \\
\hline edu & $\begin{array}{c}0.0016^{* * *} \\
(4.39)\end{array}$ & $\begin{array}{c}0.0016^{* * *} \\
(4.47)\end{array}$ & $\begin{array}{c}0.0016^{* * *} \\
(4.48)\end{array}$ \\
\hline labor_rd & $\begin{array}{c}3.7476^{\star * *} \\
(4.28)\end{array}$ & & \\
\hline $\mathrm{RD}^{*}$ labor_rd & $\begin{array}{c}13.0953 \\
(0.44)\end{array}$ & & \\
\hline firm_rd & & $\begin{array}{c}2.2330^{\star *} \\
(2.01)\end{array}$ & \\
\hline $\mathrm{RD}^{\star}$ firm_rd & & $\begin{array}{c}59.6200^{*} \\
(1.84)\end{array}$ & \\
\hline college_rd & & & $\begin{array}{c}17.2223^{\star \star \star} \\
(5.39)\end{array}$ \\
\hline $\mathrm{RD}^{*}$ college_rd & & & $\begin{array}{c}120.4807 \\
(1.00)\end{array}$ \\
\hline Intercept term & $\begin{array}{c}-0.1415^{\star * \star} \\
(-20.39)\end{array}$ & $\begin{array}{c}-0.1306^{\star * *} \\
(-15.13)\end{array}$ & $\begin{array}{c}-0.1400^{* * *} \\
(-21.46)\end{array}$ \\
\hline
\end{tabular}

a. ${ }^{*}, * * * *$, at $10 \%, 5 \%, 1 \%$ significant level.

investment in material resources on $R \& D$ efficiency within the enterprise is not significant. Human resources investment and enterprise internal knowledge activities, R\&D activities are more closely linked. Regional R\&D investment in human resources gave birth to talent, will enhance the efficiency of enterprise knowledge acquisition, knowledge integration. However, the investment and purchase of material assets in the region as an innovative element that have a direct impact on NPD performance of the enterprise by providing R\&D infrastructure.

\section{Conclusion and Inspiration}

\subsection{Conclusion}

The empirical results show that regional R\&D investment as a regional innovation impacts the performance of NPD directly and significantly, which meets the 
Table 8. Results of further research.

\begin{tabular}{|c|c|c|}
\hline ent variabl & $\& D$ investment in human resources & al resou \\
\hline $\mathrm{RD}$ & $\begin{array}{c}1.5484^{\star * *} \\
(7.80)\end{array}$ & $\begin{array}{c}1.5434^{\star * *} \\
(7.704)\end{array}$ \\
\hline subsidy & $\begin{array}{c}0.0172^{* * *} \\
(13.29)\end{array}$ & $\begin{array}{c}0.0172^{* * *} \\
(13.29)\end{array}$ \\
\hline ownership & $\begin{array}{c}-0.0036^{\star * *} \\
(-2.75)\end{array}$ & $\begin{array}{c}-0.0036^{* * *} \\
(-2.72)\end{array}$ \\
\hline size & $\begin{array}{c}0.0157^{* * *} \\
(44.69)\end{array}$ & $\begin{array}{c}0.0157^{* * *} \\
(44.69)\end{array}$ \\
\hline wage & $\begin{array}{c}0.0056^{* * *} \\
(5.59)\end{array}$ & $\begin{array}{c}0.0056^{* * *} \\
(5.63)\end{array}$ \\
\hline edu & $\begin{array}{c}0.0016^{* * *} \\
(4.49)\end{array}$ & $\begin{array}{c}0.0016^{* * *} \\
(4.47)\end{array}$ \\
\hline wage_rd & $\begin{array}{c}7.9421^{\star * *} \\
(6.07)\end{array}$ & \\
\hline $\mathrm{RD}^{*}$ wage_rd & $\begin{array}{c}86.2877^{*} \\
(1.71)\end{array}$ & \\
\hline inf_rd & & $\begin{array}{c}7.1944^{* * *} \\
(4.87)\end{array}$ \\
\hline $\mathrm{RD}^{*}$ inf_rd & & $\begin{array}{c}82.6873 \\
(1.55)\end{array}$ \\
\hline Intercept term & $\begin{array}{c}-0.1308^{* * *} \\
(-20.60)\end{array}$ & $\begin{array}{c}-0.1316^{* * *} \\
(-19.30)\end{array}$ \\
\hline
\end{tabular}

a. *, **, ***, at $10 \%, 5 \%, 1 \%$ significant level.

hypothesis of innovation factor. R\&D investment in other enterprises in the region, regional R\&D investment in human resources will have a significant impact on the enterprise internal R\&D efficiency. Then they can change the NPD performance of enterprise, which meets the innovation efficiency hypothesis. From the perspective of KBV, it shows that there is a stronger correlation of knowledge-based activities among enterprises compared with R\&D institutions and universities. In addition, talents generated from R\&D investment in human resources will improve the efficiency of enterprise internal knowledge acquisition and integration.

The possible contributions of this paper are mainly reflected in the following two aspects.

- Regional R\&D investment as a driving force for external knowledge activities and a part of the regional environment can promote NPD performance of enterprises. Most of the empirical research on this subject has been proved from the side, for example, the existence of regional research alliances will significantly affect the innovation of enterprises. However, the direct empirical research does not exist yet. This article makes up for the blank in this respect.

- Theoretical circles on the micro-mechanism of regional environmental impact on enterprise innovation are still debating. There are two main theories. First, the regional environment will directly affect the enterprise innovation, and second, the regional environment will affect the efficiency of use of innovative resources. That is to adjust the relationship between R\&D invest- 
ment and enterprise innovation. In this paper, two kinds of microscopic mechanism of action are tested by empirical way, which adds a new evidence for the research in this field.

\subsection{Policy Suggestions}

The policy significance of the conclusions is that the mechanisms of different regional R\&D investment affecting the NPD performance of enterprises are different. Both the hypothesis of innovation factor and the hypothesis of innovation efficiency have been established. Corresponding policies should be formulated according to the specific condition and objective.

- We should increase regional R\&D investment. The innovation factor theory considers that the development of new product is the result of $\mathrm{R} \& \mathrm{D}$ factor investment. As a basic factor in NPD, regional R\&D investment can exert a direct effect on the performance of NPD. Regional R\&D investment improves NPD performance of enterprises by providing various key resources needed for the development of new products, such as human resources, key knowledge and problem-solving methods.

- We should expand and consolidate the status of enterprises as the core of R\&D. The theory of innovation efficiency shows that there is a stronger correlation between knowledge activities among enterprises in the region and the stronger spillover effect of $R \& D$ investment among enterprises in the region. To increase the effect of social R\&D resources, the society should invest more resources in enterprises and subsidize $\mathrm{R} \& \mathrm{D}$ activities of enterprises. And government should make enterprises play a decisive role in the allocation of resources for $\mathrm{R} \& \mathrm{D}$, which is conducive to the transformation of the fruits of knowledge activities among different enterprises.

- We should increase regional R\&D investment in human resources. In the mechanism of R\&D investment spillover, the subject of human resources has always been the focus of domestic research. This paper verifies the role of $\mathrm{R} \& \mathrm{D}$ investment in human resources in the spillover effect from the side. So we should increase the R\&D investment in human resources and expand the spillover benefit of R\&D investment.

\subsection{Limitation of Research}

This article contains at least the following deficiencies.

- Limited by data access, older data may have an impact on the empirical results. Once new data is available in the future, test hypotheses can be tested again.

This article lacks corresponding mathematical analysis in part 2. We can make further theoretical proof.

\section{References}

[1] Madhavan, R. and Grover, R. (1998) From Embedded Knowledge to Embodied 
Knowledge: New Product Development as Knowledge Management. Journal of Marketing, 62, 1-12. https://doi.org/10.2307/1252283

[2] Wang, J.H. (2015) Analysis of the Effect of Government Subsidy on R\&D Activities and New Product Development of Enterprises. Statistic and Decision, No. 12, 178-180.

[3] Wang, X.Q. and Shen, J.L. (2016) Enterprise R\&D Investment and New Product Development Performance in the Context of Financing Constraints-Analysis of Panel Model Based on Chinese Industrial Enterprise Database. Science and Technology Management Research, No. 11, 131-138.

[4] Li, Z.Y. and Zhao, S.G. (2011) Impact of Intersectoral Integration and R\&D Intensity on the Success of New Product Development-An Empirical Study Based on Biomedical Enterprises. Scientific Research, 29, 50-55.

[5] Hanel, P. and Stpierre, M. (2006) Industry-University Collaboration by Canadian Manufacturing Firms. The Journal of Technology Transfer, 31, 484-499. https://doi.org/10.1007/s10961-006-0009-5

[6] Zhou, M., Liu, B.-Y. and Sheng, X.-Y. (2013) Influence of Innovation Process, Innovation Environment and Its Cross-Level Interaction on Innovation. Finance and Economics Research, 39, 4-18.

[7] Baron, R.M. and Kenny, D.A. (1986) The Moderator-Mediator Variable Distinction in Social Psychological Research: Conceptual, Strategic, and Statistical Considerations. Journal of Personality and Social Psychology, 51, 1173-1182. https://doi.org/10.1037/0022-3514.51.6.1173

[8] Nonaka, I. (1994) A Dynamic Theory of Organizational Knowledge Creation. Organization Science, 5, 14-37.

[9] Xu, B., Li, X.D. and Zhang, X. (2011) Research on the Influence Mechanism of Regional Environment on Enterprise Innovation Performance. Scientific Research Management, 32, 147-156.

[10] Nonaka, I. and Takeuchi, H. (1995) The Knowledge Creating: How Japanese Companies Create the Dynamics of Innovation. Oxford University Press, New York, 4-24.

[11] Grant, R.M. (1996) Toward a Knowledge-Based Theory of the Firm. Strategic Management Journal, 17, 109-122. https://doi.org/10.1002/smj.4250171110

[12] Caner, T. and Tyler, B.B. (2015) The Effects of Knowledge Depth and Scope on the Relationship between R\&D Alliances and New Product Development. Journal of Product Innovation Management, 32, 808-824. https://doi.org/10.1111/jpim.12224

[13] Hu, Y.P. and Liu, X.M. (2008) Study on Knowledge Innovation Process in Knowledge Alliance. Journal of Economics and Management, No. 7, 31-34.

[14] Katila, R. and Ahuja, G. (2002) Something Old, Something New: A Longitudinal Study of Search Behavior and New Product Introduction. Academy of Management Journal, 45, 1183-1194. https://doi.org/10.2307/3069433

[15] Grant, R.M. (1997) The Knowledge-Based View of the Firm: Implications for Management Practice. Long Range Planning, 30, 450-454. https://doi.org/10.1016/S0024-6301(97)00025-3

[16] Prabhu, J.C., Chandy, R.K. and Ellis, M.E. (2005) The Impact of Acquisitions on Innovation: Poison Pill, Placebo, or Tonic? Journal of Marketing, 69, 114-130. https://doi.org/10.1016/S0024-6301(97)00025-3

[17] Zhou, K.Z. and Li, C.B. (2012) How Knowledge Affects Radical Innovation: Knowledge Base, Market Knowledge Acquisition, and Internal Knowledge Sharing. Stra- 
tegic Management Journal, 33, 1090-1102. https://doi.org/10.1002/smj.1959

[18] Polanyi, M. (1966) The Tacit Dimension. Routledge \& Kegan Paul, London, 5-10.

[19] Wei, J. and Wang, T.A. (2006) An Empirical Study on the Influential Factors of Knowledge Transfer among Individuals, Groups and Organizations. Science of Sciences, 24, 91-97.

[20] Yuan, L.X. and Xuan, G.L. (2002) Knowledge Creation Mechanism: Epistemology-Ontology Perspective. Science Management Research, 20, 7-9.

[21] Ji, H.S., Lu, Q. and Wang, H.W. (2011) Study on Knowledge Innovation Spiral in Product Development Process. Scientific Research Management, 32, 22-27.

[22] Kogut, B. and Zander, U. (1992) Knowledge of the Firm, Combinative Capabilities, and the Replication of Technology. Organization Science, 3, 383-397.

[23] Cai, H.B. and Liu, Q. (2009) Competition and Corporate Tax Avoidance: Evidence from Chinese Industrial Firm. The Economic Journal, 119, 764-795. https://doi.org/10.1111/j.1468-0297.2009.02217.x

[24] Xie, Q.L., Luo, S.J. and Zhang, Y.F. (2008) Growth and Convergence of Industrial Productivity in China. The Quarterly Journal of Economics, 7, 809-826.

[25] Lei, L. and Zhang, L. (2002) The Principle and Application of Multi-Layer Linear Model. Journal of Capital Normal University, No. 2, 110-114.

[26] Fang, J., Wen, Z.L., Liang, D.M. and Li, N.N. (2015) Analysis of the Adjustment Effect Based on Multiple Regression. Psychological Science, 38, 715-720. 